\title{
An Improved Method for Evaluating Regional Resource Carrying Capacities: A Case Study of the Tarim River Basin in Arid China
}

\author{
Fei Wang ${ }^{1 *}$, Changjian Wang ${ }^{2 *}$, Yuyao $\mathrm{Ye}^{2}$, Bin Wen ${ }^{3 *}$ \\ ${ }^{1}$ Xinjiang Laboratory of Lake Environment and Resources in Arid Zone, Research Centre \\ for Urban Development of the Silk Road Economic Belt, College of Geography Science and Tourism, \\ Xinjiang Normal University, Urumqi 830054, Xinjiang, China \\ ${ }^{2}$ Key Laboratory of Guangdong for Utilization of Remote Sensing and Geographical Information System, \\ Guangdong Open Laboratory of Geospatial Information Technology and Application, \\ Guangzhou Institute of Geography, Guangzhou 510070, China \\ ${ }^{3}$ College of Economic and Management, Huanghuai University, Zhumadian 463000, China
}

Received: 14 March 2018

Accepted: 15 May 2018

\begin{abstract}
Resource endowment and resource carrying capacity (RCC) are the most important cornerstones of regional sustainable development. By applying a newly established RCC method, namely, the relative resources carrying capacity (RRCC) method, we evaluated the RCC in the Tarim River basin (TRB) in arid China in Xinjiang during 2000-2011. Research results show that the relative resources carrying capacity can be effectively served as indicators of regional resources sustainable development status. Taking Xinjiang as the reference region, the TRB can be characterized as an area with an overloaded population and surplus economy during the whole research period, where land resources are relative advantage resources carrying the regional population growth and economic development and water resources are relative disadvantage resources restricting rapid regional development. Taking TRB as the reference region, 42 counties and cities in TRB performed significant temporal and spatial disparities according to the RRCC based on population and economic perspectives. Based on the spatial-temporal evolution of RRCC, 42 counties and cities in TRB were classified into four matching modes (A, B, C, and D). The spatial-temporal evolution characteristics and mechanisms about the 42 prefectures and cities were examined, and the suitable development strategies for every different mode were recommended.
\end{abstract}

Keywords: resource carrying capacity (RCC), relative resource carrying capacity model (RRCC), Tarim River basin (TRB), spatial-temporal evolution, arid China

*e-mail: wangfei09@mails.ucas.ac.cn, wwwangcj@126.com, yellowriverwenbin@163.com 


\section{Introduction}

Resource carrying capacity (RCC) is an objective phenomenon that reflects the support capacity of population growth, economic development, and ecological environmental protection in a country/ region [1-4]. The concept of "carrying capacity" was originally proposed by Park and Burgess in human ecology, which was defined as the number of individuals an environment can support with food availability [5]. After nearly a century of development, theory, and concept, the method of "carrying capacity" was widely applied and constantly improved upon [6, 7]. RCC is one of the most popular and noted branches of the carrying capacity. Research fields of RCC included but are not limited to water resources carrying capacity (WRCC) [8-14], land resources carrying capacity (LRCC) [15$19]$, grassland carrying capacity $[20,21]$, ocean carrying capacity [22-24], environment carrying capacity [2528], and ecological carrying capacity [29-32], etc. LRCC and WRCC were studied especially broadly and deeply at the global, national, and local scales. And then research perspectives of RCC expanded from the single water or land resources to the comprehensive natural resources [33], economic resources [34, 35], and social resources [36]. Based on the traditional RCC method, the assessment results always show that resources and environmental carrying capacity have been achieved at full capacity or overloading state in these case-studies conducted in China [37, 38] - a country characterized by huge population scale and scarce natural resources. Aiming to avoid the absoluteness of the traditional RCC method, the relative resources carrying capacity (RRCC) model was established, introduced, and applied after 2000 [39, 40]. Then, the RRCC method was popularly applied to estimate RCC in China at the provincial and regional scales [41-45]. Taking one or several geographical proximity $[46,47]$ areas that were bigger than the study areas as the reference areas, the different types of RRCC in the study areas were calculated according to resources amount in the reference areas and resources reserve in the study areas [48-50]. Compared with the traditional RCC methods, the RRCC methods emphasized the complementarity between the advantage resources and disadvantage resources [49, 50]. Recently, the RRCC methods were mostly adopted to evaluate RCC in the province-level and the city-level, such as Sichuan [41], Gansu [45], Xinjiang [42, 51], Ningxia [43], and Jiangsu provinces [40], and the cities of Baiyin [52], Chongqing [53], etc. However, there are still some key issues in the application of the RRCC methods that should be addressed. Meanwhile, some key regions should be comprehensively researched to verify the applicability of the RRCC model and highlight the most important influencing factors affecting regional sustainable development. Currently, Resources and environment carrying capacity assessment were served as government management tools in China both at the national and regional levels. But there were significant regional disparities across different regions within China, especially the inland revier basin in arid China. Resources and environmental carrying capacity assessment in China should highlight the regional disparities in the process of implementation.

The Tarim River basin (Fig. 1), China's largest inland river basin, is a typical fragile ecological environment area in an arid zone in northwestern China in Xinjiang [54-57] - one of the most underdeveloped provinces in Northwest China - and the TRB is an underdeveloped region in Xinjiang. The unreasonable utilization of water and soil resources at the current stage has caused an imbalance of water conditions in the upper and lower reaches to maintain the ecological environment in the TRB [58, 59], and vegetation degradation and desertification have threatened the social and economic sustainable development of the TRB [60]. However, population growth, industrial development, and urbanization in recent years have accelerated the contradiction between the supply and demand of water and soil resources in the TRB due to the limited resources endowment and unreasonable resources utilization [51, 59, 61]. Yang et al. illustrated that counties and cities based on oasis farming in the TRB were heavily dependent on land and water resources, and the shortages of land and water resources would severely restrict the development of oasis farming and urbanization [62]. Chang et al. revealed that water resources utilization efficiency was the key element for the expansion of cultivated land in TRB [63]. Guo et al. stated that the exploration of water and land resources in the TRB has led to increasingly violent water supply and demand contradiction - especially in dry years [64]. It is a matter of urgency for the TRB to consider how to correctly view sustainable development and how to scientifically grasp the resources carrying capacity of water and land in this region. In addition, policies, measures, and suggestions based on the whole basin perspective cannot be effectively and efficiently implemented $[49,54,57,59,61]$, as well as taking full account of resource endowment, development stage, and spatial differences, etc. across the different prefectures and cities in the TRB.

\section{Material and Methods}

\section{Data Materials}

In this case study, population size and economic scale were selected as the objects of the resources carrying capacity. Population size and economic scale are the total population and the gross domestic product (GDP) in each county and city in TRB. Natural resources mainly include water and land resources, which were closely related to economic and social activities. Water resources were the total available water resources in each county and city in TRB. Land resources were the total crop-sown areas and the construction land 


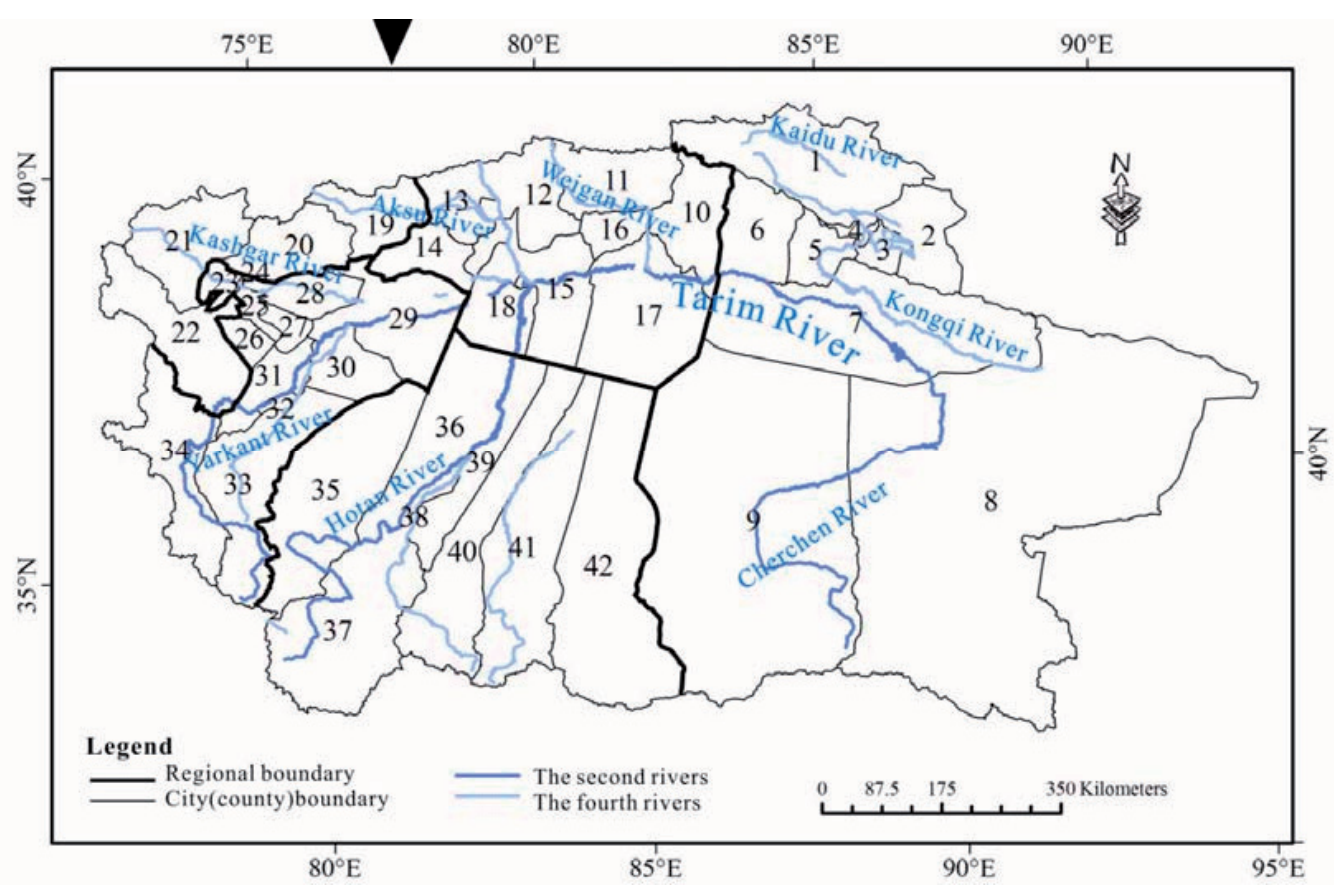

Fig.1. Location and overviews of the Tarim River basin in Xinjiang.

Note: Codes 1 to 9 represent Hejing county, Hoxud county, Bohu County, Yanqi Hui Autonomous county, Korla city, Luntai county, Yuli county, Ruoqiang county, and Qiemo county in Bayangol Mongol Autonomous Prefecture; Codes 10 to18 represent Kuqa county, Baicheng county, Wensu county, Wushi county, Kalpin county, Aksu city, Xinhe county, Xayar county, and Awat county in Aksu Administrative Offices; Codes 19 to 22 represent Akqi county, Artux city, Wuqia county, and Akto county in Kizilsu Kirgiz Autonomous Prefecture; Codes 23 to 34 represent Shufu county, Kashgar city, Shule county, Yengisar county, Yopurga county, Jiashi county, Bachu county, Makit county, Shache county, Zepu county, Yecheng county, and Taxkorgan Tajik Aotonomous County in Kashgar Administrative Offices; Codes 35 to 42 represent Pishan county, Moyu county, Hotan county, Hotan city, Lop county, Qira county, Yutian county, and Minfeng county in Hotan Administrative Offices.

areas in each county and city in TRB. Population and economic data were collected from the Xinjiang Fifty Years (1955-2005) and the Xinjiang Statistical Yearbook (2000-2012). Economic scale data was measured by GDP in Chinese yuan in time series from 2000 to 2011. Natural resources, including the total available water resources, the total crop sown areas, and the construction land areas, were collected from Xinjiang Statistical Yearbooks (2000-2013), Xinjiang Water Resources Bulletin (2000-2012), and Xinjiang City County Building Statistical Yearbooks (2000-2012) compiled by the Xinjiang Statistical Bureau.

\section{Relative Resources Carrying Capacity Model}

Compared with the RCC method, the RRCC method started relatively late $[39,40]$. The main development process of the RRCC [48-50] was that the research object extended from single resource (i. e., water resource, land resource, etc.) to integrated resources including the natural resources represented by water, land and other resources, economic resources represented by gross domestic product (GDP), and social resources represented by social network and interpersonal connections, etc.

The traditional RRCC method adopted the integrated land resource, water resource, and economic resource to evaluate the relative resources carrying capacity of population, while adopted land resource and water resource to evaluate the relative resources carrying capacity of economy in the study region $[39,40]$.

Relative land resource carrying capacity of population $R R C C_{\text {Population }}^{\text {Land }}$ :

$$
C_{p l}=\frac{P_{0}}{Q_{l 0}} \times Q_{l}
$$

Relative water resource carrying capacity of population $R R C C_{\text {Population }}^{\text {Wate }}$ :

$$
C_{p w}=\frac{P_{0}}{Q_{w 0}} \times Q_{w}
$$

Relative economic resource carrying capacity of population $R R C C_{\text {Population }}^{\text {Economy }}$ : 


$$
C_{p g}=\frac{P_{0}}{Q_{e c 0}} \times Q_{e c}
$$

Relative resources carrying capacity of population $R R C C_{\text {Population : }}$

$$
C_{s p}=W_{l} C_{p l}+W_{w} C_{p w}+W_{g} C_{p g}
$$

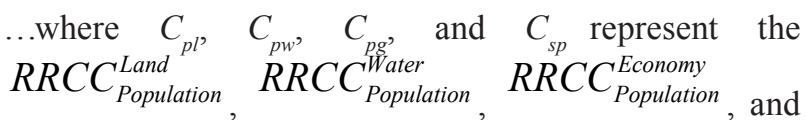
$R R C C_{\text {Population }}$, respectively. $P_{0}$ represents the total population in the reference region, $Q_{10}$ represents the total area of land resource in the reference region, $Q_{w 0}$ represents the total water resource in the reference region, and $Q_{e c 0}$ represents the GDP in the reference region. $Q_{l}, Q_{w}$, and $Q_{e c}$ represent the total area of land resource, the total water resource, and GDP in the study region, respectively. $W_{l}, W_{w}$, and $W_{e c}$ represent the weight coefficients of $C_{p l}, C_{p w}$, and $C_{p g}$, while $W_{l}+W_{w}+W_{e c}=1$.

In Eq. (4), the $C_{s p}$ was identified by the linear weighted sum method [37, 38]. By comparing the theoretical value of $C_{s p}$ with the actual population size, the population development trend in the study region was judged in advance.

Relative land resource carrying capacity of economy $R R C C_{\text {Economy }}^{\text {Land }}$ :

$$
C_{g l}=\frac{G_{0}}{Q_{l 0}} \times Q_{l}
$$

Relative water resource carrying capacity of economy $R R C C_{\text {Economy }}^{\text {Water }}$ :

$$
C_{g w}=\frac{G_{0}}{Q_{w 0}} \times Q_{w}
$$

Relative resources carrying capacity of economy $R R C C_{\text {Economy : }}$

$$
C_{s g}=W_{l}^{\prime} C_{g l}+W_{w}^{\prime} C_{g w}
$$

$\ldots$ where $C_{g l}, C_{g w}$, and $C_{s g}$ represent the $R R C C_{\text {Economy }}^{\text {Land }}$,
$R R C C_{\text {Economy }}^{\text {Water }}$, and $R R C C_{\text {Economy }}$, respectively. $G_{0}$ represents the total GDP in the reference region, $Q_{l 0}$ represents the total area of land resource in the reference region, and $Q_{w 0}$ represents the total water resource in the reference region. $Q_{l}$ and $Q_{w}$ represent the total area of land resource and the total water resource in the study region, respectively. $W_{l}^{\prime}$ and $W_{w}^{\prime}$ represent the weight coefficients of $C_{g l}$ and $C_{g w}$, while $W_{l}^{\prime}+W_{w}^{\prime}=1$.

In Eq. (7), $C_{s g}$ was identified by the linear weighted sum method [37, 38]. By comparing the theoretical value of $C_{s g}$ with the actual GDP, the economic development trend in the study region was judged in advance.

\section{Improved Relative Resources Carrying Capacity Model}

So far, the method applied for calculating the RRCC is not yet mature. The linear weighted sum method is still the popular way to identify the weight coefficients [37-40]. The biggest defect of this method is the subjectivity and randomness during the process of weight coefficients selection [48-50], which affects the science of this method. In order to overcome the subjectivity and randomness in the original model, we improved the RRCC method by using the principle of advantage resource traction effect and disadvantage resource constraint effect [48-50]. The advantage resource traction effect means that the weight coefficients can be identified when $C_{s p}$ and $C_{s g}$ reach their maximum values within the scope of constraint conditions. The disadvantage resource traction effect means that the weight coefficients can be identified when $C_{s p}$ and $C_{s g}$ reach their minimum values within the scope of constraint conditions. By constructing a linear programming model and using linear interactive and general optimizer software, the optimal solution combined with the objective weight coefficients were determined [48-50].

Taking the relative resources carrying capacity of population $\left(R R C C_{\text {Population }}\right)$ and the relative resources carrying capacity of the economy ( $R R C C_{E c o n o m y}$ ) as examples, the formulas are as follows:

$$
\begin{gathered}
C_{s p}^{\max }=w_{1} C_{p l}+w_{2} C_{p w}+w_{3} C_{p g} \\
C_{s p}^{\min }=w_{1} C_{p l}+w_{2} C_{p w}+w_{3} C_{p g} \\
C_{s g}^{\max }=w_{1} C_{g l}+w_{2} C_{g w} \\
C_{s g}^{\min }=w_{1} C_{g l}+w_{2} C_{g w}
\end{gathered}
$$

...where $C_{s p}^{\max }$ and $C_{s p}^{\min }$ represent the maximum value and minimum value of the $R R C C_{\text {Population }}$, and $C_{s g}^{\max }$ and $C_{s g}^{\min }$ represent the maximum value and minimum value of the $R R C C_{E c o n o m y}$. The constraint conditions in Eqs. (8-11) are $\alpha \leq\left|w_{i}-w_{j}\right| \leq \beta$, $\delta<w_{i}, w_{j}<1,(i, j=1,2,3$, 且 $\mathrm{i} \neq j), \quad \sum_{i=1}^{3} w_{i}=1, \quad$ and $\sum_{j=1}^{3} w_{j}=1 . \delta$ is the lower limit of the weight coefficients. 
Table.1 Criterias and formulas for the classification and degree of carrying capacity state.

\begin{tabular}{|c|c|c|}
\hline & Criteria for classifying carrying state & Formulas for the degrees of carrying state \\
\hline & \multicolumn{2}{|c|}{ Relative resources carrying capacity of population } \\
\hline Super overload & $P-C_{s p}^{\max }>0$ & $\eta_{s}^{\text {superoverload }}=\left(P-C_{s p}^{\max }\right) / C_{s p}^{\max }$ \\
\hline Overload & $P-\left(C_{s p}^{\max }+C_{s p}^{\min }\right) / 2>0$ & $\eta_{s}^{\text {overload }}=\left[2 P-\left(C_{s p}^{\max }+C_{s p}^{\min }\right)\right] /\left(C_{s p}^{\max }+C_{s p}^{\min }\right)$ \\
\hline Critical & $P-\left(C_{s p}^{\max }+C_{s p}^{\min }\right) / 2=0$ & $\varepsilon_{s}=0$ \\
\hline Surplus & $P-\left(C_{s p}^{\max }+C_{s p}^{\min }\right) / 2<0$ & $\psi_{s}^{\text {surplus }}=\left[\left(C_{s p}^{\max }+C_{s p}^{\min }\right)-2 P\right] /\left(C_{s p}^{\max }+C_{s p}^{\min }\right)$ \\
\hline \multirow[t]{2}{*}{ Super surplus } & $P-C_{s p}^{\min }<0$ & $\psi_{s}^{\text {supersurplus }}=\left(C_{s p}^{\min }-P\right) / C_{s p}^{\min }$ \\
\hline & \multicolumn{2}{|c|}{ Relative resources carrying capacity of economy } \\
\hline Super overload & $G-C_{s g}^{\max }>0$ & $\eta_{s}^{\text {superoverload }}=\left(G-C_{s g}^{\max }\right) / C_{s g}^{\max }$ \\
\hline Overload & $G-\left(C_{s g}^{\max }+C_{s g}^{\min }\right) / 2>0$ & $\eta_{s}^{\text {overload }}=\left[2 G-\left(C_{s g}^{\max }+C_{s g}^{\min }\right)\right] /\left(C_{s g}^{\max }+C_{s g}^{\min }\right)$ \\
\hline Critical & $G-\left(C_{s g}^{\max }+C_{s g}^{\min }\right) / 2=0$ & $\varepsilon_{s}=0$ \\
\hline Surplus & $G-\left(C_{s g}^{\max }+C_{s g}^{\min }\right) / 2<0$ & $\psi_{s}^{\mathrm{su} r p l u s}=\left[\left(C_{s g}^{\max }+C_{s g}^{\min }\right)-2 G\right] /\left(C_{s g}^{\max }+C_{s g}^{\min }\right)$ \\
\hline Super surplus & $G-C_{s g}^{\min }<0$ & $\psi_{s}^{\text {supersurplus }}=\left(C_{s g}^{\min }-G\right) / C_{s g}^{\min }$ \\
\hline
\end{tabular}

$\beta$ and $\alpha$ are the upper and lower limits of the weight difference between $C_{p l}, C_{p w}$, and $C_{p g}$, or between $C_{g l}$ and $C_{g w^{*}}$
At present, most of the research results divide the carrying status of the RCC model into three states: overload, surplus, and critical. The overload state

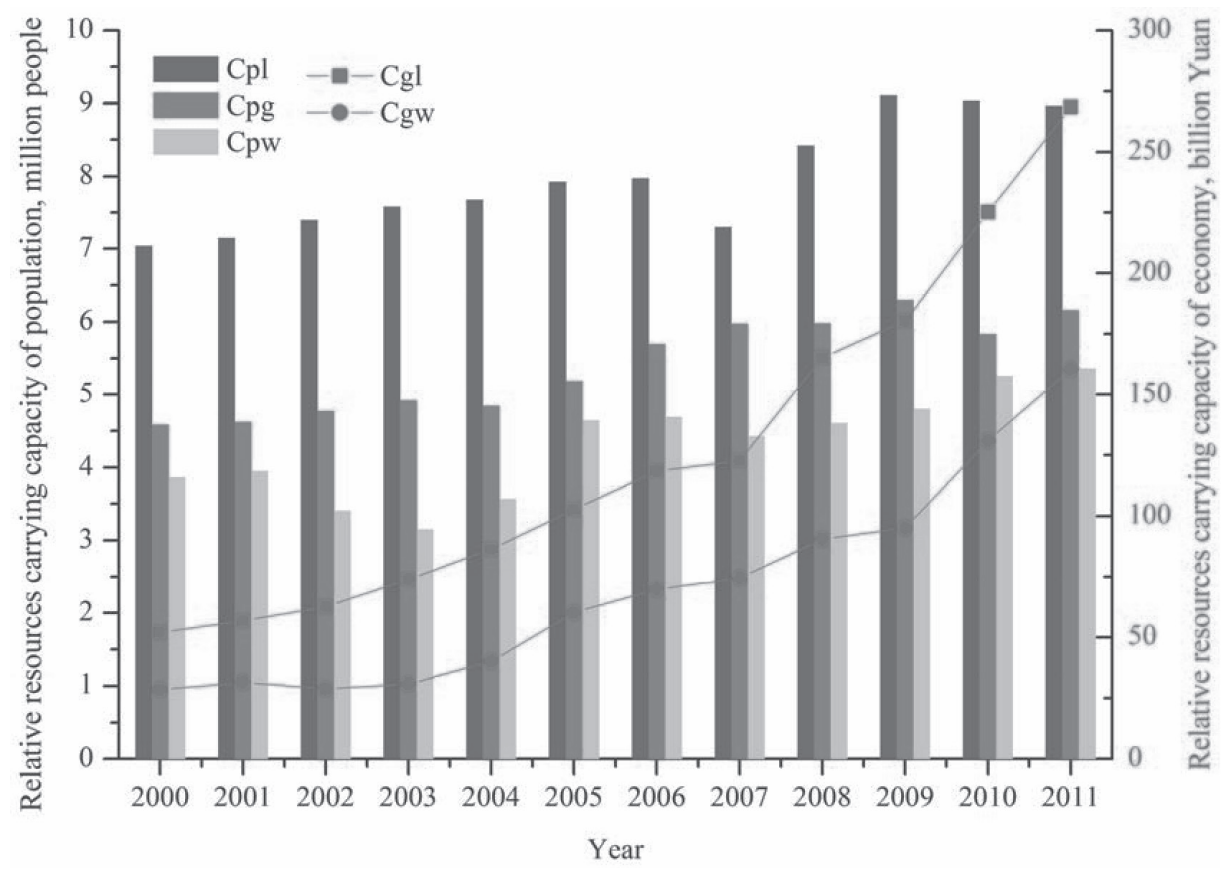

Fig. 2. Evolution process of $C_{p l}, C_{p g}, C_{p w}, C_{g l}$, and $C_{g w}$ in TRB during 2000-2011. 
and surplus state were not further divided [48-50]. Therefore, it is not possible to distinguish the degrees between two surplus areas or two overloading areas. In view of this, we further divide the carrying status into five states in our newly improved RRCC method: super overload, overload, critical, surplus, and super surplus (Table 1).

\section{Results and Discussion}

\section{Relative Resources Carrying Capacity in TRB Taking Xinjiang as Reference}

Taking Xinjiang as the reference region, the advantageous and disadvantageous position of land resources, water resources, and economic resources in TRB compared with Xinjiang were explored.

According to the Eq. (1), (2), and (3), the relative land resource carrying capacity of population $\left(C_{p}\right)$, the relative economic resource carrying capacity of population $\left(C_{p g}\right)$, and the relative water resource carrying capacity of population $\left(C_{p w}\right)$ were calculated from 2000 to 2011 in TRB (Fig. 2) Compared with Xinjiang, the largest RRCC of population was the land resources, which was followed by economic and water resources. This indicated that land resources was the relative advantage resource for population development in the TRB, while the water resources was the relative disadvantage resource that played a constraint effect on population development during the research period. According to the Eq. (5) and (6), the relative land resource carrying capacity of economy $\left(C_{g}\right)$, and the relative water resource carrying capacity of population $\left(C_{g w}\right)$ were calculated (Fig. 2). Compared with Xinjiang, the largest RRCC of the economy was land resources, followed by water resources. This indicated that land resources were the relative advantage resource for economic development in the TRB, while water resources were the relative disadvantage resource that played a constraint effect on economic growth during the research period.

The dominant economic development mode in the TRB was agriculture-based economic activities. Relatively lagging economic development made the economic resources play a relative minor contribution to the RRCC of population in the TRB compared with Xinjiang. Traditional oasis agricultural production activities occupied a large amount of water resources with the low efficiency in the utilization of water resources in the TRB [58, 59]. Recently, the upstream three main sources of water (i.e., the Aksu, the Kashgar, and the Hotan rivers) flowing to the mainstream in the TRB showed a decreasing trend, coupled with the growing demands of domestic and industrial water resources resulting from urbanization and industrialization progress [54], which led to the increasing contradiction between supply and demand of water resources and ecological environmental degradation. Irrational use of water resources in the TRB made the contribution of water resources to the RRCC of population and the economy relatively small compared with that of land resources. The intensification of desertification in recent years has caused the oasis land area to become a relatively scarce resource in the TRB [60]. The contributions of land resources to the RRCC of population and the economy were more obviously prominent during the whole research period. The appropriate expansion of artificial oases and the improvement of land use efficiency [61] should be continuously enhanced in the TRB while giving full play to the comparative advantages of land resources in the future, in order to ensure the stability and sustainability of oasis development.

Table 2. Relative resources carrying capacity of population and the carrying state in the TRB.

\begin{tabular}{|c|c|c|c|c|c|c|}
\hline & Cspmin & Cspmax & Csp & Carrying state & $\eta$ & Overloaded population of scale \\
\hline 2000 & 4.631 & 5.699 & 5.165 & Super overload & 0.480 & 3.270 \\
\hline 2001 & 4.700 & 5.784 & 5.242 & Super overload & 0.484 & 3.339 \\
\hline 2002 & 4.553 & 5.832 & 5.192 & Super overload & 0.501 & 3.562 \\
\hline 2003 & 4.522 & 5.911 & 5.216 & Super overload & 0.506 & 3.687 \\
\hline 2004 & 4.695 & 6.031 & 5.363 & Super overload & 0.512 & 3.756 \\
\hline 2005 & 5.356 & 6.487 & 5.922 & Super overload & 0.454 & 3.510 \\
\hline 2006 & 5.588 & 6.657 & 6.122 & Super overload & 0.443 & 3.482 \\
\hline 2007 & 5.464 & 6.340 & 5.902 & Super overload & 0.499 & 3.603 \\
\hline 2008 & 5.731 & 6.946 & 6.338 & Super overload & 0.398 & 3.370 \\
\hline 2009 & 6.050 & 7.428 & 6.739 & Super overload & 0.340 & 3.218 \\
\hline 2010 & 6.054 & 7.361 & 6.707 & Super overload & 0.389 & 3.515 \\
\hline 2011 & 6.223 & 7.438 & 6.830 & Super overload & 0.410 & 3.657 \\
\hline
\end{tabular}


Table. 3 Relative resources carrying capacity of economy and the carrying state in the TRB.

\begin{tabular}{|l|l|l|l|l|l|c|}
\hline & Csgmin & Csgmax & Csg & Carrying state & $\psi$ & Surplus economies of scale \\
\hline 2000 & 36.690 & 43.720 & 40.210 & Super surplus & 0.078 & 6.380 \\
\hline 2001 & 40.310 & 47.950 & 44.130 & Super surplus & 0.088 & 7.370 \\
\hline 2002 & 40.660 & 50.780 & 45.720 & Super surplus & 0.006 & 5.320 \\
\hline 2003 & 45.850 & 58.810 & 52.330 & Surplus & 0.083 & 4.350 \\
\hline 2004 & 56.310 & 70.180 & 63.250 & Super surplus & 0.031 & 8.690 \\
\hline 2005 & 75.090 & 87.840 & 81.460 & Super surplus & 0.105 & 14.280 \\
\hline 2006 & 86.790 & 101.410 & 94.100 & Super surplus & 0.025 & 9.460 \\
\hline 2007 & 91.380 & 105.840 & 98.610 & Overload & 0.019 & -1.920 \\
\hline 2008 & 116.710 & 139.160 & 127.930 & Surplus & 0.082 & 10.510 \\
\hline 2009 & 125.010 & 150.610 & 137.810 & Super surplus & 0.001 & 12.870 \\
\hline 2010 & 163.960 & 192.190 & 178.070 & Super surplus & 0.113 & 32.690 \\
\hline 2011 & 198.230 & 230.590 & 214.410 & Super surplus & 0.070 & 29.980 \\
\hline
\end{tabular}

According to the Eq. (8) and (9), we calculated the relative resources carrying capacity of population in the TRB by determining the maximum and minimum values of $C_{s p}$ (Table 2). Then we divided the carrying state based on the degrees of carrying state according to the classification criteria in Table 1 . Over the past 12 years, the carrying state of $C_{s p}$ has been in a state of super overload in the TRB. During the period of the super overload, the $C_{\text {spmin }}, C_{s p m a x}, C_{s p}$, and the overloaded population of scale were performing overall increasing trends. This indicated that the actual population scale in the TRB has significantly exceeded the relative RCC of population during the whole research period. In view of the evolving process of the degrees of carrying state, the $\eta^{\text {super overload }}$ of $C_{s p}$ has been declining significantly since 2004, and then performed a trend of slow growth. In the near future, more attention should be effectively paid to curb the growth trend of the carrying state degrees of the $C_{s p}$ (Table 3).

According to the Eqs. (10) and (11), we calculated the relative RCC of the economy in the TRB by determining the maximum and minimum values of $C_{s g}$. Then we divided the carrying state based on the degrees of carrying state according to the classification criteria in Table 1 . Over the past 12 years, the carrying state of $C_{s g}$ has always been in a state of surplus in the TRB, with surplus states in 2003 and 2008, and an overload state in 2007. During the period of the super overload, $C_{\text {sgmin }}, C_{\text {sgmax }}, C_{s g}$, and the surplus economies of scale were performing overall increasing trends. The surplus GDP and the degrees of super surplus carrying state of $C_{s g}$ have obviously increased after 2009. This indicated that the actual economic scale in the TRB failed to give full play to the resource advantage compared with the relative RCC of the economy, and has great potential for economic growth.

\section{Spatiotemporal Evolution Processes of the RRCC in TRB}

The relative resources carrying capacity of population with the surplus carrying state were mainly located in the Bayangol Mongol Autonomous Prefecture and other counties and cities in the Aksu Administrative Offices in the TRB. The relative resources carrying capacity of population in Bayinguoleng Mongolian Autonomous Prefecture were performing the very surplus carrying state since 2000. In view of the changes of the degrees of carrying state, the degrees of very surplus carrying state in Korla city decreased gradually, while that of Luntai, Ruoqiang, and Qiemo counties continued to increase and that of Yuli, Yanji Hui Autonomous, Hoxud, and Bohu counties performed fluctuating downward trends in the Bayangol Mongol Autonomous Prefecture. In the Aksu Administrative Offices, there were only Aksu city and Kuqa County in very surplus carrying states. The degrees of very surplus carrying states in Aksu city decreased in a fluctuating manner. The degrees of carrying state in Kuqa County was very surplus after 2000, and the surplus population was performing an increasing trend.

The relative RCC of population with the overload carrying state were mainly located in the Hotan Administrative Offices, Kashgar Administrative Offices, Kizilsu Kirgiz Autonomous Prefecture, and other counties and cities in the Aksu Administrative Offices in the TRB. All of the counties and cities in Hotan Administrative Offices, Kashgar Administrative Offices, and Kizilsu Kirgiz Autonomous Prefecture except the cities of Kashgar and Hotan were performing super overload carrying state in view of $C_{s p}$. In 2000, the maximum value of the degrees of super overload carrying state was $87.91 \%$ in Moyu County, which was 8.25 times the minimum value of the degrees of super 
overload carrying state in Yopurga County. In 2011, the maximum value of the degrees of super overload carrying state was $161.26 \%$ in Moyu County, which was 48.87 times the minimum value of the degrees of super overload carrying state in Zepu County. This indicated that region disparities were performing an increasing trend on the spatial scale. In view of the changes of the degrees of carrying state, the degrees of super overlodad carrying state in Wushi County, Wuqia County, and other counties in Hotan Administrative Offices increased gradually, while that of Kalpin, Shufu, Shule, Shache, and Yecheng counties decreased gradually.

The relative resources carrying capacity of the economy with the overload carrying state were mainly located in the Bayangol Mongol Autonomous Prefecture and Aksu city in the Aksu Administrative Offices in the TRB. The relative resources carrying capacity of the economy in Bayinguoleng Mongolian Autonomous Prefecture were performing the super overload carrying state since 2000 except Qiemo and Bohu counties. The relative resources carrying capacity of economy with the overload carrying state were located in the Kaidu RiverKongqi River basin in Bayangol Mongol Autonomous Prefecture. In view of the changes of the degrees of carrying state, the degrees of super overload carrying state in Korla city and Hejing County first increased and then decreased, while that of Yuli and Yanji Hui Autonomous counties decreased gradually and that of Ruoqiang county increased gradually. In 2000, the maximum value of the degrees of super overload carrying state was $75.03 \%$ in Yuli County, which was 23.5 times of the minimum value of the degrees of super overload carrying state in Bohu County. In 2011, the maximum value of the degrees of super overload carrying state was $365.13 \%$ in Ruoqiang County, which was 41.26 times the minimum value of the degrees of super overload carrying state in Luntai County. This indicated that regional disparities were performing an increasing trend on the spatial scale. The carrying state of $C_{s g}$ in Aksu city were super overload during the whole research period except in 2000 and 2004, and the degrees of super overload carrying state increased first and then decreased in a fluctuating manner.

The relative resources carrying capacity of the economy with the surplus carrying state were mainly located in the Hotan Administrative Offices, Kashgar Administrative Offices, Kizilsu Kirgiz Autonomous Prefecture, and other counties and cities in the Aksu Administrative Offices in the TRB. In view of the changes of the degrees of carrying state, the degrees of very surplus carrying state in Zepu County and Makit County increased gradually, while that of the cities of Hotan, Artux, and Kashgar decreased gradually.

As a whole, the Kashgar, Yarkant, and Hotan river basins in Kizilsu Kirgiz Autonomous Prefecture, Kashgar Administrative Offices, and Hotan Administrative Offices in the TRB were performing with super overload or overload carrying state on population and very surplus carrying state on economy, while the Kaidu-Kongqi River basin in Bayangol Mongol Autonomous Prefecture in the TRB were performing with very surplus carrying state on population and super overload carrying state on economy. After nearly 10 years of development and evolution, the relative resources carrying capacity of population and economy still failed to break the spatial pattern with a serious unbalanced distribution in the TRB.

\section{Influence Mechanism Analysis on the Evolution of RRCC in the TRB}

Population growth and geographical expansion are the main external manifestations of urbanization [54, $65,66]$. In the past 12 years, the urbanization level (calculated as the share of non-agricultural population) of the five main cities in the TRB has a highly positive correlation with the degrees of very surplus carrying state of $C_{s p}$. The cities in the TRB with the highest urbanization level were also showing strong population aggregation. Korla and Aksu were the two cities with the highest urbanization levels in the TRB, with a high level of degrees of very surplus carrying state of $C_{s p}$. Kashgar city, one of the five main cities with the third highest urbanization level in the TRB and whose carrying state of $C_{s p}$ changed from surplus to very surplus with the improvement of its urbanization level and the degrees of very surplus carrying state, increased gradually. The urbanization level in Hotan city was relatively low, and its degrees of very surplus carrying state of $C_{s p}$ was also relatively low. The urbanization level in Atushi city was the lowest in the five provincial capital cities in the TRB, which was $25.09 \%$ in 2011 . The carrying state of $C_{s p}$ in Atushi city was always super overloaded during the whole research period. Hotan, Moyu, and Lop counties were located in the Hotan River basin, with a fragile desert oasis ecosystem. The poor resources environment endowment combined with the underdevelopment of productive forces made the GDP growth of this region slow. The urbanization level in Hotan, Moyu, and Lop counties were only $4.86 \%$, $8.82 \%$, and $11.26 \%$ in 2011 , respectively. In addition, the total sown area of crops in Hotan county and Moyu County increased slowly in recent years, while the total sown area of crops in Lop County performed a slowly decreasing trend as a result of the ecological environment evolution and desertification. Under such comprehensive influences, the carrying state of $C_{s p}$ in Hotan, Moyu, and Lop counties was always super overloaded, which played a significant effect on the stable development of the oasis. This indicated that the relative resources carrying capacity of population and the population absorption capacity of counties and cities could be increased by promoting the urbanization level in the TRB. The implementation of appropriate population transfer measures in the basin would mitigate the ecological environment pressure resulting from 
population scale in the counties with the super overload carrying state of $C_{s p}$.

The dominant economic development mode in the TRB was traditional agriculture economic activities with the obvious characteristics of oasis agricultural economy based on water resources. Agricultural production in the TRB was excessively dependent on the utilization of water resources. Traditional oasis agricultural production relied on the increase of arable land in oases and irrigation water resources. Low utilization of land and water resources led to the very surplus carrying state of $C_{s g}$ in the Hotan Administrative Offices, Kashgar Administrative Offices, Kizilsu Kirgiz Autonomous Prefecture, and especially the Hotan Administrative Offices. Water resource utilization efficiency in Hotan city was $13.391 \mathrm{~m}^{3} /$ thousand yuan in 2000 and $3.816 \mathrm{~m}^{3} /$ thousand yuan in 2011, while that of Aksu city was $5.835 \mathrm{~m}^{3} /$ thousand yuan in 2000 and $1.476 \mathrm{~m}^{3} /$ thousand yuan in 2011, and that of Korla city was $3.674 \mathrm{~m}^{3} /$ thousand yuan in 2000 and $1.108 \mathrm{~m}^{3} /$ thousand yuan in 2011. This indicated that low utilization of land and water resources made the contribution of water resources and land resources to economic growth have not yet been brought into full play in the TRB. Akesu city is a typical oasis agricultural city located in the Aksu basin. In recent years, with the development of mineral resources (oil and natural gas), the proportion of the output value of the secondary industry continued to increase and the utilization efficiency of water resources and land resources also performed a rapid growth trend. Korla city, the regional economic center in the TRB, is an important industrial city located in the Kaidu-Kongqi basin, whose oil industry is highly developed. As well as Hejing, Luntai, and Yuli counties in the Kaidu-Kongqi basin and Ruoqiang County in the Qarqan River basin, mineral resources development enhanced the RCC of economy to some extent.

Since the implementation of the "western development" strategy after 2000, the economic development in the TRB has been promoted to some extent. The main components of the strategy include the development of infrastructure and investments aimed at stimulating economic growth and improving the living standards of residents in western China. The national government successively implemented agricultural tax relief after 2000, then the "one black [oil] and one white [cotton]" strategy was conducted in the TRB. Prices of grain and cotton continued to rise during this period. Reclamation of reclaimed land and the abandonment of cultivated land increased rapidly combined with the improvement of water conservancy facilities in the $\mathrm{TRB}$, making the carrying capacity of land resources increase gradually - especially counties and cities in Aksu Administrative Offices and Shache, Makit, and Bachu counties in Kashgar Administrative Offices, whose $C_{g l}$ improved significantly in this period. Along with the operation of South Xinjiang Railway and the continuous improvement of railway capacity extending to Hotan city, counties and cities located along the South Xinjiang Railway became rapid development areas with concentrated exploitation and utilization of land resources, such as Shache, Bachu, Awat, Kuqa, Xayar, and Yecheng counties.

\section{Evaluating Regional Sustainable Development in the Counties and Cities in the TRB}

In order to get more scientific and effective evaluation of the sustainable development in the counties and cities in the TRB (Table 4), 42 counties and cities in area were classified into four matching modes according to the $C_{s p}$ and $C_{s g}:$ A) relative resources carrying capacity of population and economy were overloaded; B) relative resources carrying capacity of population were overload and relative resources carrying capacity of economy were surplus; C) relative resources carrying capacity of population were surplus and relative resources carrying capacity of economy were overload; and D) relative resources carrying capacity of population and economy were surplus. According to Table 4, matching modes in the counties and cities in the TRB performed significant spatial differences during the whole research period. Kashgar, Yarkant, and Hotan river basins in the western TRB were B-type gathering regions. The Kaidu-Kongqi basin in the eastern TRB were C-type gathering regions.

During the whole research period, Awat county in Aksu Administrative Offices in the TRB was the only county that experienced four matching types from C-type to A-type, then to B-type, and then to D-type, which indicated that the development model of Awat County was relatively unstable. Awat was a traditional agricultural county in TRB that lacks mineral resources and oil and gas resources, but is rich in light and heat resources. The proportion of the primary industry was more than 45\% during 2000 to 2011 in Awat County, and its cotton industry accounted for more than $60 \%$ of the industrial added value. Awat was a typical oasis characterized by the "cotton economy" and is affected by fluctuations in cotton prices. The cotton-sown area in Awat has been growing at an unstable rate in recent years. At the same time, cotton cultivation is a high-water consuming industry. Under circumstances of uncertain water supply and unstable cotton-sown areas, the cotton industry in Awat would inevitably exacerbate the contradiction between the water use among various industries, and further affected the water resources carrying capacity of the economy. The double uncertainty of water supply and cotton economy may to some extent aggravate the unstable development model in Awat. Six counties experienced three matching types: Luntai, Wensu, Kuqa, Akqi, Taxkorgan Tajik Autonomous, and Minfeng. Ten counties experienced two matching types: Yanji Hui Autonomous, Hejing, Hoxud, Bohu, Xayar, Baicheng, Wuqia, Zepu, Makit, and Bachu. Other counties and cities in the TRB experienced one matching type, which indicates that the development model of these counties and cities in 
Table 4. Changes of matching modes in each county and city in the TRB based on the relative resources carrying capacity.

\begin{tabular}{|c|c|c|c|c|c|c|c|c|c|c|c|c|c|c|}
\hline Code & Counties/Cities & 2000 & 2001 & 2002 & 2003 & 2004 & 2005 & 2006 & 2007 & 2008 & 2009 & 2010 & 2011 & Modes \\
\hline & \multicolumn{14}{|c|}{ Yarkant river basin - Kashgar river basin } \\
\hline 1 & Kashgar City & $\mathrm{D}$ & $\mathrm{D}$ & $\mathrm{D}$ & $\mathrm{D}$ & $\mathrm{D}$ & $\mathrm{D}$ & $\mathrm{D}$ & $\mathrm{D}$ & $\mathrm{D}$ & $\mathrm{D}$ & $\mathrm{D}$ & $\mathrm{D}$ & 1 \\
\hline 2 & Shufu County & B & B & B & B & B & B & B & B & B & B & B & B & 1 \\
\hline 3 & Shule County & B & B & $\mathrm{B}$ & B & B & B & B & B & B & B & B & B & 1 \\
\hline 4 & $\begin{array}{l}\text { Yengisar } \\
\text { County }\end{array}$ & B & B & B & B & B & B & B & B & B & B & B & B & 1 \\
\hline 5 & Zepu County & B & B & B & B & B & B & B & B & B & $\mathrm{D}$ & B & B & 2 \\
\hline 6 & Shache County & B & B & B & B & B & B & B & B & B & B & B & B & 1 \\
\hline 7 & $\begin{array}{l}\text { Yecheng } \\
\text { County }\end{array}$ & B & B & B & B & B & B & B & B & B & B & B & B & 1 \\
\hline 8 & Makit County & B & $\mathrm{D}$ & $\mathrm{D}$ & $\mathrm{D}$ & B & B & B & B & B & B & $\mathrm{D}$ & B & 2 \\
\hline 9 & $\begin{array}{l}\text { Yopurga } \\
\text { County }\end{array}$ & B & B & B & B & B & B & B & B & B & B & B & B & 1 \\
\hline 10 & Jiashi County & B & B & B & B & B & B & B & B & B & B & B & B & 1 \\
\hline 11 & Bachu County & B & B & $\mathrm{D}$ & B & B & B & B & B & $\mathrm{D}$ & B & B & B & 2 \\
\hline 12 & $\begin{array}{c}\text { Taxkorgan Tajik } \\
\text { Autonomous } \\
\text { County }\end{array}$ & B & B & B & $\mathrm{D}$ & $\mathrm{D}$ & $\mathrm{D}$ & $\mathrm{D}$ & A & A & A & B & B & 3 \\
\hline 13 & Artux City & B & B & B & B & B & B & B & B & B & B & B & B & 1 \\
\hline 14 & Akto County & B & B & B & B & B & B & B & B & B & B & B & B & 1 \\
\hline 15 & Akqi County & B & A & A & A & A & B & B & $\mathrm{B}$ & B & A & A & $\mathrm{C}$ & 3 \\
\hline \multirow[t]{2}{*}{16} & Wuqia County & A & $\mathrm{A}$ & A & A & A & A & A & A & A & A & B & B & 2 \\
\hline & \multicolumn{14}{|c|}{ Aksu river basin - Weigan river basin } \\
\hline 17 & Aksu City & $\mathrm{C}$ & $\mathrm{C}$ & $\mathrm{C}$ & $\mathrm{C}$ & $\mathrm{C}$ & $\mathrm{C}$ & $\mathrm{C}$ & $\mathrm{C}$ & $\mathrm{C}$ & $\mathrm{C}$ & $\mathrm{C}$ & $\mathrm{C}$ & 2 \\
\hline 18 & Wensu County & A & $\mathrm{D}$ & $\mathrm{D}$ & B & B & B & B & B & B & $\mathrm{D}$ & B & B & 3 \\
\hline 19 & Kuqa County & A & $\mathrm{D}$ & $\mathrm{C}$ & $\mathrm{D}$ & $\mathrm{D}$ & $\mathrm{D}$ & $\mathrm{D}$ & $\mathrm{D}$ & $\mathrm{D}$ & $\mathrm{D}$ & $\mathrm{D}$ & $\mathrm{D}$ & 3 \\
\hline 20 & Xayar County & $\mathrm{D}$ & $\mathrm{D}$ & $\mathrm{D}$ & $\mathrm{D}$ & $\mathrm{D}$ & $\mathrm{D}$ & $\mathrm{D}$ & B & B & B & $\mathrm{B}$ & $\mathrm{B}$ & 2 \\
\hline 21 & Xinhe County & B & B & B & B & B & B & B & B & B & B & B & B & 1 \\
\hline 22 & $\begin{array}{l}\text { Baicheng } \\
\text { County }\end{array}$ & B & B & B & B & B & A & B & A & A & A & A & A & 2 \\
\hline 23 & Wushi County & B & B & B & B & B & B & B & B & B & B & B & B & 1 \\
\hline 24 & Awat County & $\mathrm{C}$ & $\mathrm{C}$ & A & A & A & A & B & B & B & $\mathrm{D}$ & B & $\mathrm{D}$ & 4 \\
\hline \multirow[t]{2}{*}{25} & Kalpin County & B & B & B & B & B & B & B & B & B & B & B & B & 1 \\
\hline & \multicolumn{14}{|c|}{ Hotan river basin } \\
\hline 26 & Hotan City & B & B & B & B & B & B & $\mathrm{B}$ & $\mathrm{B}$ & $\mathrm{B}$ & $\mathrm{B}$ & $\mathrm{B}$ & $\mathrm{B}$ & 1 \\
\hline 27 & Hotan County & B & B & B & B & B & B & B & B & B & B & B & B & 1 \\
\hline 28 & Moyu County & B & B & B & B & B & B & B & B & B & B & B & B & 1 \\
\hline 29 & Pishan County & B & B & B & B & B & B & B & B & B & B & B & B & 1 \\
\hline 30 & Lop County & B & B & B & B & B & B & B & B & B & B & B & B & 1 \\
\hline 31 & Qira County & B & B & B & B & B & B & B & B & B & B & B & B & 1 \\
\hline 32 & Yutian County & B & B & B & B & B & B & B & B & B & B & B & B & 1 \\
\hline 33 & $\begin{array}{l}\text { Minfeng } \\
\text { County }\end{array}$ & B & B & B & B & D & B & B & B & B & A & A & A & 3 \\
\hline
\end{tabular}


Table 4. Continued.

\begin{tabular}{|c|c|c|c|c|c|c|c|c|c|c|c|c|c|c|}
\hline & \multicolumn{10}{|c|}{ Kaidu river-Kongqi river basin } \\
\hline 34 & Korla City & C & C & C & C & C & C & C & C & C & C & C & C & 1 \\
\hline 35 & Luntai County & D & D & A & C & C & C & C & C & C & C & C & C & 3 \\
\hline 36 & Yuli County & C & C & C & C & C & C & C & C & C & C & C & C & 1 \\
\hline 37 & $\begin{array}{c}\text { Yanji Hui } \\
\text { Autonomous } \\
\text { County }\end{array}$ & C & C & C & C & C & C & C & D & D & C & C & C & 2 \\
\hline 38 & Hejing County & C & C & A & A & A & A & A & A & A & A & C & C & 2 \\
\hline 39 & Hoxud County & C & C & C & C & C & C & D & D & D & C & D & D & 2 \\
\hline 40 & Bohu County & C & C & C & C & D & D & D & D & D & D & D & D & 2 \\
\hline & \multicolumn{10}{|c|}{} & \multicolumn{10}{|c|}{ Qarqan river basin } & & & \\
\hline 41 & $\begin{array}{c}\text { Ruoqiang } \\
\text { County }\end{array}$ & C & C & C & C & C & C & C & C & C & C & C & C & 1 \\
\hline 42 & Qiemo County & D & D & D & D & D & D & D & D & D & D & D & D & 1 \\
\hline
\end{tabular}

the TRB are relatively stable. Hotan and Artush cities were all B-type from 2000 to 2011. Korla and Aksu cities were all C-type during 2000 to 2011. Kashgar city was D-type from 2000 to 2011.

A-type regions' relative resources carrying capacities of population and economy were overloaded. The population is relatively saturated and the economic development is relatively sufficient. The industrial structure should be further optimized to maintain sustainable economic development. The population pressure should be reduced with the implementation of appropriate population diversion measures in order to improve the regional capacities for sustainable development. No one county in the TRB was always staying in A-type development patterns during 2000 to 2011. Only a few counties experienced A-type development patterns within a certain period of time. Baicheng County's development pattern changed from B-type to A-type in recent years. The main reason for the transformation was that coal production and sales in Baicheng expanded rapidly as a result of the improvement of traffic and logistics conditions in the TRB and the rapid growth of external demand during the research period. The advantages in mineral resources have turned into more economic resources, and Baicheng GDP rapidly increased. Mineral resources exploitation played an obvious accelerated effect on the economic growth in the initial stage of regional development. However, the sustainable utilization of regional mineral resources was based on the reasonable exploitation and utilization and the balance between supply and demand. Mineral resources-based cities and counties in the TRB should pay more attention to orderly exploitation and realize advantageous resource transformation, so as to avoid the possible "resource curse" phenomenon.

B-type regions' relative resources carrying capacity of population were overload and relative resources carrying capacity of economy were surplus. Economic development in these counties and cities was relatively inadequate. Most counties and cities in the TRB were B-type development patterns, and these counties and cities were key development zones. Counties and cities with B-type development patterns were mainly located in the Hotan, Yarkant, and Kashgar river basins. The industrial structures of the B-type regions were relatively single and these industrial development levels were relatively backward. The regional economy in these B-type regions has limited capacities to absorb the population and the unit GDP occupying a large amount of natural resources. In addition, the utilization efficiency of water resources and land resources were relatively low compared with other counties and cities in the TRB. In the future, these B-type regions should attach importance to the optimization and upgrading of industrial structure and the improvement of resource exploitation and utilization efficiency in order to promote rapid economic development. More efforts should be effectively made to promote the population absorption capacity of regional economy, supplemented by appropriate population outflow measures such as migrant workers and labor force transfer.

C-type regions' relative resources carrying capacity of population were surplus, and relative resources carrying capacity of the economy were overloaded. The population pressures in these regions were relatively small, and economic development in these regions was adequate. C-type regions were optimizing development zones in the TRB. Counties and cities with C-type development patterns were mainly located in the Kaidu-Kongqi basin in Bayangol Mongol Autonomous Prefecture and Aksu city. Industrial development in C-type regions was characterized by obvious industrialization trends. In the TRB, which was dominated by traditional oasis agricultural production, the newly emerging industrial economy promoted 
the rapid economic growth in C-type regions. The RCC of population and economy were also improved during the industrialization process. During the process of industrialization in C-type regions, more attention should be paid to the protection of ecological environment and the orderly exploitation of mineral resources, and the sustainable utilization of water resources and land resources. Korla and Aksu cities, the regional economic centers in the TRB, should give full play to their ability of absorbing a foreign labor force in the process of rapid economic development, supplemented by appropriate population inflow measures.

D-type regions' relative resources carrying capacity of population and economy were surplus. Natural resources in D-type regions were relatively rich, and the advantage resource traction effect in these regions fails to be fully tapped to promote economic development. Population pressure in Kashgar city was relatively small, and the water resources and land resources were relatively abundant. More attention should be paid to enhance the exploration and utilization of land resources and water resources and the improvement of resources utilization efficiency. Furthermore, special attention should be seriously paid to fully enjoy the special economic policies of the Kashgar special economic zone announced by the national government in 2010, aiming to cultivate a new regional economic center in southern Xinjiang to promote its economic radiation ability and population absorption capacity. Relying on the construction of "Kuqa-Baicheng coal base," the development of coal resources and the construction of industrial parks have made great progress in Kuqa County's industrial economy. However, the GDP of Kuqa accounted for only $5 \%$ of the total GDP in the TRB, and Kuqa consumed nearly $10 \%$ of the total water resources in the TRB. In the future, Kuqa should focus on improving water resource utilization efficiency as the main objective.

\section{Conclusions}

By applying a newly established RRCC model, we evaluated the process of regional sustainable development in the TRB in arid China in Xinjiang during 2000-2011. The improved RRCC model has some practical values in optimizing the current method. The RRCC can effectively serve as an indicator of sustainable development status. Studying the resources and environmental carrying capacity in the inland river basin (i.e., the TRB) in arid land in China, the RRCC model to some extent can play a more significant role in overcoming the drawbacks of absoluteness of the traditional RCC method.

Taking Xinjiang as the reference region, the TRB can be characterized as an area with overload population and surplus economy during the whole research period, where land resources are relative advantage resources carrying the regional population growth and economic development, and water resources are relative disadvantage resources restricting the regional rapid development in TRB.

Taking TRB as the reference region, 42 counties and cities in TRB performed significant temporal and spatial disparities according to the RRCC based on the population and economic perspectives. The Kashgar, Yarkant, and Hotan river basins in Kizilsu Kirgiz Autonomous Prefecture, Kashgar Administrative Offices, and Hotan Administrative Offices in the TRB were performing with super overload or overload carrying state on population and very surplus carrying state on the economy, while the Kaidu-Kongqi basin in performed with very surplus carrying state on population and super overload carrying state on economy. Urbanization process, industrial development, and policy measures played significant effects on the spatiotemporal evolution processes of the relative RCC in TRB. But the relative resources carrying capacity of population and economy still failed to break the spatial pattern with a serious unbalanced distribution in the TRB after nearly 10 years of development and evolution.

Based on the spatial-temporal evolution of RRCC, 42 counties and cities in TRB were classified into four matching modes (i.e., A, B, C, and D). Most counties and cities in the TRB were B-type development patterns, and these counties and cities were key development zones. Industrial development in C-type regions was characterized by an obvious industrialization trend. C-type regions were optimizing development zones in the TRB. In the future, appropriate development scales and reasonable development patterns should be effectively determined by the resources carrying capacity in order to promote the sustainable development of the TRB.

\section{Acknowledgments}

This work was supported by the Xinjiang Laboratory of Lake Environment and Resources in Arid Zone, Xinjiang Uygur Autonomous Region Key Laboratory Foundation (XJDX0909-2015-03), the Research Centre for Urban Development of the Silk Road Economic Belt, the " $13^{\text {th }}$ Five-Year" Plan for Key Discipline Bidding Project, Xinjiang Normal University (No: 17SDKD0703), the Xinjiang Normal University Doctoral Research Foundation (XJNUBS1538), the Hundreds of Young Doctors Introduction Program of Xinjiang, Xinjiang Normal University (BS2016004), the National Natural Science Foundation of China (41501144, 41671130, 41661037, 41361043), the GDAS' Project of Science and Technology Development (2016GDASRC-0101, 2017GDASCX-0101, 2018GDASCX-0101, 2019GDASYL-0302001). 


\section{Conflict of Interest}

The authors declare no conflict of interest.

\section{References}

1. HUI C. Carrying capacity, population equilibrium, and environment's maximal load. Ecol Model, 192, 317, 2006.

2. ARROW K., BOLIN B., COSTANZA R., DASGUPTA P., FOLKE C., HOLLING C.S., JANSSON B.-O., LEVIN S., M LER K.-G., PERRINGS C., PIMENTEL D. Economic Growth, Carrying Capacity, and the Environment. Science, 268, 520, 1995.

3. ROUGHGARDEN J. Population Dynamics in a Spatially Varying Environment: How Population Size "Tracks" Spatial Variation in Carrying Capacity. The American Naturalist, 108, 649, 1974.

4. MCLEOD S.R. Is the concept of carrying capacity useful in variable environments? Oikos, 79, 529, 1997.

5. PARK R.E., BURGESS E.W. An introduction to the science of sociology. Chicago: The University of Chicago Press, 1921.

6. WANG S.-X., SHANG M., ZHOU Y., LIU W.-L., WANG F., WANG L.-T. Resources and Environmental Carrying Capacity Using RS and GIS. Pol J Environ Stud, 26, 2793, 2017.

7. ACCATINO F., WARD D., WIEGAND K., DE MICHELE C. Carrying capacity in arid rangelands during droughts: the role of temporal and spatial thresholds. Animal, 11, 309, 2017.

8. WANG T., XU S. Dynamic successive assessment method of water environment carrying capacity and its application. Ecol Indicators, 52,134,2015.

9. ZUO Q., MA J., GAO C. Study on carrying capacity of urban water environment. Advances in Water Science, 16, 103, 2005.

10. MAJOR M., CIESLINSKI R. Retentivity as an Indicator of the Capacity of Basins without an Outlet to Accumulate Water Surpluses. Pol J Environ Stud, 24, 2503, 2015.

11. ZHOU X.-Y., LEI K., MENG W., KHU S.-T. Industrial structural upgrading and spatial optimization based on water environment carrying capacity. Journal of Cleaner Production, 165, 1462, 2017.

12. ZHOU R., PAN Z., JIN J., LI C., NING S. Forewarning Model of Regional Water Resources Carrying Capacity Based on Combination Weights and Entropy Principles. Entropy, 192017.

13. LIU H., LIU Y., LI L., GAO H. Study of an evaluation method for water resources carrying capacity based on the projection pursuit technique. Water Science and Technology-Water Supply, 17, 1306, 2017.

14. FU Z.H., ZHAO H.J., WANG H., LU W.T., WANG J., GUO H.C. Integrated planning for regional development planning and water resources management under uncertainty: A case study of Xining, China. JHyd, 554, 623, 2017.

15. GU K., LIU J., DOU J. Response of Ecological Carrying Capacity of Resource-Type Cities to Changes in Land Use. Journal of Ecology and Rural Environment, 23, 7, 2007.

16. SHAO X., ZHANG H. Estimation of the Labor Carrying Capacity of Land Resources in the Northwestern Shandong. Journal of Natural Resources, 19, 324, 2004.

17. KRAJEWSKI P. Assessing Change in a High-Value Landscape: Case Study of the Municipality of Sobotka, Poland. Pol J Environ Stud, 26, 2603, 2017.
18. BABY S., NATHAWAT M.S., AL-SARAWI M.A. Major Impacts from Anthropogenic Activities on Landscape Carrying Capacity of Kuwaiti Coast. Pol J Environ Stud, 23, 7, 2014.

19. FONSECA J., BASSO E., SERRANO D., NAVEDO J.G. Effects of tidal cycles on shorebird distribution and foraging behaviour in a coastal tropical wetland: Insights for carrying capacity assessment. ECSS, 198, 279, 2017.

20. SURINA, ZU J., JIN H., CHAOLUMENGQIQIGE, WANG Z., CHAMUHA, NA Y., LI J. Changes in Grassland Productivity and Livestock Carrying Capacity in Inner Mongolia. Ecology and Environmental Sciences, 26, 605, 2017.

21. DUAN C., SHI P., ZHANG X., ZONG N., CHAI X., GENG S., ZHU W. The Rangeland Livestock Carrying Capacity and Stocking Rate in the Kailash Sacred Landscape in China. Journal of Resources and Ecology, 8, $551,2017$.

22. NIELSEN J.L., RUGGERONE G.T. Climate Change and a Dynamic Ocean Carrying Capacity: Growth and Survival of Pacific Salmon at Sea. In: Knudsen EE, Michael JH, editors. Pacific Salmon Environmental and Life History Models: Advancing Science for Sustainable Salmon in the Future, 77, 2009.

23. SARKER S., WILTSHIRE K.H. Phytoplankton carrying capacity: Is this a viable concept for coastal seas? Ocean Coast Manage, 148, 1, 2017.

24. MA P., YE G., PENG X., LIU J., QI J., JIA S. Development of an index system for evaluation of ecological carrying capacity of marine ecosystems. Ocean Coast Manage, 144, 23, 2017.

25. LIU R.Z., BORTHWICK A.G.L. Measurement and assessment of carrying capacity of the environment in Ningbo, China. J Environ Manage, 92, 2047, 2011.

26. LOPEZ J.C.C., BHAKTIKUL K. Sustainable Environment and Tourism Industry: An Institutional Policy Analysis of Northeastern Thailand. Pol J Environ Stud, 27, 31, 2018.

27. ZHANG M., LIU Y., WU J., WANG T. Index system of urban resource and environment carrying capacity based on ecological civilization. Environ Impact Assess Rev, 68, 90, 2018.

28. LEVI CUPUL-MAGANA A., PAOLA RODRIGUEZTRONCOSO A. Tourist carrying capacity at Islas Marietas National Park: An essential tool to protect the coral community. Applied Geography, 88, 15, 2017.

29. BYRON C., LINK J., COSTA-PIERCE B., BENGTSON D. Calculating ecological carrying capacity of shellfish aquaculture using mass-balance modeling: Narragansett Bay, Rhode Island. Ecol Model, 222, 1743, 2011.

30. PRATO T. Fuzzy adaptive management of social and ecological carrying capacities for protected areas. J Environ Manage, 90, 2551, 2009.

31. XU L., YANG X., WANG K., LI X., ZHANG M. Research progress in ecological carrying capacity. Ecology and Environment, 15, 1111, 2006.

32. TANG M., WU D., FU X., CAO H. An assessment of ecological carrying capacity of Xilingol, Inner Mongolia. Int J Sustain Dev World Ecol, 24, 408, 2017.

33. LI X., MENG M. Optimum population analysis of Jilin Province, China based on comprehensive carrying capacity. Chinese Journal of Applied Ecology, 28, 3378, 2017.

34. BROWN M.T., ULGIATI S. Emergy measures of carrying capacity to evaluate economic investments. Popul Environ, 22, 471, 2001. 
35. CUADRA M., BJORKLUND J. Assessment of economic and ecological carrying capacity of agricultural crops in Nicaragua. Ecol Indicators, 7, 133, 2007.

36. LEUJAK W., ORMOND R.F.G. Visitor perceptions and the shifting social carrying capacity of south sinai's coral reefs. Environ Manage, 39, 472, 2007.

37. LI Z., DONG S., TANG S. Model Modification and Empirical Analysis of the Relative Carrying Capacity of Resources. Resources Science, 30, 1336, 2008.

38. HUANG C., HE L. Model Modifications and Empirical Analysis of the Relative Carrying Capacity of Resources. Resources Science, 33, 41, 2011.

39. LIU Z., YU X. Carrying capacity of resources and problems of sustainable development in yangtze basin. Resources and Environment in the Yangtze Valley, 11, 10, 2002.

40. HE M., LIU Y. Relative carrying capacity of resources and problems of sustainable development in Jiangsu Province. China Population-Resources and Environment, 13, 81, 2003

41. PENG Z., GUO S. Research on the Relative Carrying Capacity of Resources Based on Improved Model in the Southwest District of China: A Case Study in Ya'an City of Sichuan Province. Areal research and development, 153, 2018.

42. CHEN W., LI J., WU K., FAN X. Model modification and empirical analysis of the relative carrying capacity of resources in Xinjiang. Arid Land Geography, 453, 2017.

43. AN Y., ZHOU L., YANG G., CHEN Y., LU H. Relative carrying capacity of resources in Yanchi county of Ningxia. Journal of Desert Research, 399, 2017.

44. FU Q., YANG D., ZHANG X., XIA F., WANG F. Time and space differentiation of relative carrying capacity of resources in Ili based on improved model. Journal of University of Chinese Academy of Sciences, 170, 2016.

45. BING F., CHEN Q., ZHANG D. Regional differences of relative carrying capacity of resources in Gansu pastoral area. Pratacultural science, 2587, 2016.

46. TORRE A. On the role played by temporary geographical proximity in knowledge transmission. Reg Stud, 42, 869, 2008.

47. BOSCHMA R., ERIKSSON R., LINDGREN U. How does labour mobility affect the performance of plants The importance of relatedness and geographical proximity. Journal of Economic Geography, 9, 169, 2009.

48. WANG C., WANG F., WEN B. Spatio-temporal variability of relative carrying capacity of resources in the Kaidu River-Kongque River Basin. Research of Agricultural Modernization, 37, 444, 2016.

49. WANG F., YANG D., WANG C., XIA W., YANG F. Spatiotemporal Characteristics of Sustainable Development in Xinjiang Based on Improved Relative Carrying Capacity of Resources. Journal of Desert Research, 33, 1605, 2013.

50. WANG F., YANG D., WANG C., ZHANG Y., TANG H., YIN J. Sustainable Development in Northern Slope of the Tianshan Mountains Based on Improved Model of Carrying Capacity Related to Resources. Arid Zone Research, 30, 1073, 2013.

51. WANG F., YANG D., ZHANG X., WANG C. Spatial pattern and internal differences evolvement of economy in Xinjiang at the county level. Arid Land Geography, 37, $820,2014$.
52. QIN S., NAN Z. Dynamic Analysis of Relative Carrying Capacity of Resources in Baiyin City. Research of Soil and Water Conservation, 14, 132, 2007.

53. YANG Q., LU C., WEN F., WANG Z., MAO X., MAI $X$. On Relative Carrying Capacity of Resources and Sustainable Development in Chongqing City. Research of Agricultural Modernization, 28, 314, 2007.

54. WANG C., ZHANG X., DU H., WANG F. Quantitative analysis of the dynamic relationship between urbanization level and eco-environment quantity in Xinjiang, China. Journal of Desert Research, 32, 1794, 2012.

55. WANG C., WANG F., ZHANG H. The process of energyrelated carbon emissions and influencing mechanism research in Xinjiang. Acta Ecol Sin, 36, 2151, 2016.

56. WANG C., ZHANG X., ZHANG H., WANG F. Influencing mechanism of energy-related carbon emissions in Xinjiang based on the input-output and structural decomposition analysis. Acta Geographica Sinica, 71, 1105, 2016.

57. WANG C., WANG F., ZHANG X., DU H. Quantitative analysis of the economic growth influence on urbanization and ecological environment pressure in Xinjiang. Journal of University of Chinese Academy of Sciences, 31, 206, 2014.

58. WANG C., ZHANG X., DU H., LI X. Relationship between urbanization and water use in Tarim River:a case of Bayingolin Mongol Autonomous Prefecture. Arid Land Geography, 35, 324, 2012.

59. WANG C., ZHANG X., DU H., WANG F. Comprehensive Evaluation and Analysis on the Water Resources Carrying Capacity Levels in the Kaidu-Kongqi River Basin. Journal of Glaciology and Geocryology, 34, 990, 2012.

60. ZUMRAT E., TURSUN Q., AYXAM I., MNISAHAN T., HAN G. The land-use changes and its environmental effects in Tarim River. Journal of Arid Land Resources and Environment, 25, 29, 2011.

61. WANG F., YANG D., WANG C., LIU Y., ZHANG W. Dynamic econometric analysis of interaction between agricultural land intensive utilization and economic growth:a case of Baicheng County. Arid Land Geography, 35, 1012, 2012

62. YANG Y., LIU Y. Spatio-temporal analysis of urbanization and land and water resources efficiency of oasis cities in Tarim River Basin. J Geogr Sci, 24, 509, 2014.

63. CHANG C., BAO A., LI J. Spatiotemporal Evolution of Cultivated Land in the Headwaters of the Tarim River. Arid Zone Research, 33, 239, 2016.

64. GUO H., XU H., LING H. Study of EcologicalWater Transfer Mode and Ecological Compensation Scheme of the Tarim River Basin in Dry Years. Journal of Natural Resources, 32, 1705, 2017.

65. WANG C., ZHANG X., DU H., WANG F., ZHANG X., NI T. Quantitative analysis of the dynamic relationship between urbanization and ecological environment in Urumqi,Xinjiang. Arid Land Geography, 37, 609, 2014.

66. WANG C., WANG F., WEN B. Empirical analysis of the inner relationship and mechanism of urbanization, industrialization, and agricultural and husbandry modernization in Xinjiang, China. Research of Agricultural Modernization, 36, 1007, 2015. 